Article

\title{
Updating the Path to a Carbon-Neutral Built Environment-What Should a Single Builder Do
}

\author{
Mihail Vinokurov *, Kaisa Grönman ${ }^{\circledR}$, Antti Kosonen, Mika Luoranen and Risto Soukka \\ LUT School of Energy Systems, Lappeenranta University of Technology, 53850 Lappeenranta, Finland; \\ kaisa.gronman@lut.fi (K.G.); antti.kosonen@lut.fi (A.K.); mika.luoranen@lut.fi (M.L.); risto.soukka@lut.fi (R.S.) \\ * Correspondence: mihail.vinokurov@lut.fi; Tel.: +358-50-449-1333
}

Received: 6 July 2018; Accepted: 16 August 2018; Published: 17 August 2018

\begin{abstract}
This paper proposes an extension for feasibility assessment of residential energy (heat and electricity) supply solutions in an operational environment undergoing major changes. In order to improve the life cycle economy of the energy supply, the design has to accommodate technological, economic, and regulatory changes in operational environment over the long time. New elements must be included in feasibility assessments of energy supply to ensure consideration of future economic opportunities and risks. The extended feasibility assessment brings up the profitability of "future proofed" more sustainable solutions with lower risks related to utilization costs and with improved resale value preservation. The findings of systematic literature study were structured and clarified into a decision support matrix to guide the assessment process. The procedure was verified by identifying the optimal energy supply solution for a net-zero energy single-family house in Southern Finland. The verification demonstrated that the procedure provides new insights on the economy and the climate implications of the energy solutions.
\end{abstract}

Keywords: residential energy supply; life cycle economy; technological changes; economic changes; regulatory changes; renewable energy; demand response

\section{Introduction}

The new era of digitalization and the development of renewable energy sources provides new opportunities to reach the greenhouse gas (GHG) emission reduction targets of the EU for 2050 in economically advantageous ways. At the same time, the ongoing changes in operational environment create new risks for the life cycle economy of the residential energy supply investments. Multiple energy outlook reports identified four common trends significantly affecting the future of energy networks: increase in volumes of renewable energy production, possibilities to utilize battery storage, deregulation of energy networks, and increased smartness in meters and devices [1-5].

The costs of renewable energy technologies applicable for buildings have heavily decreased during the last decade. The reasons for the decrease in costs are the technology's rapid development, mass production, and the economic steering aimed to decrease greenhouse gas emissions resulting from electricity generation. According to the IEA, the cost of solar panels has decreased by a factor of five in the past six years and the cost is still expected to halve in the next 20 years. In addition, financial incentives have been offered to renewable energy producers in many countries to decrease the greenhouse gas emissions from electricity generation [1-9].

Decreasing costs of renewable energy production have led to the remarkable increase in renewables in many electricity markets. Due to the intermittent nature of wind and solar energy production, energy production surpluses and deficits emerge in electricity markets with a high share of renewable energy production. Mismatch of supply and demand on such electricity markets leads to 
increased volatility of market prices for electricity. Clearly, the new generation technologies create a need to develop improved flexibility in electricity and district heating systems [7,9-11].

The price of energy storage technologies has declined alongside that of renewable production technologies. Battery storage is an important technology to overcome the challenges related to the intermittency of the electricity derived from renewables, such as solar panels or wind turbines. Besides loading surplus solar power, battery storage can also be used for loading overnight when the price of the electricity is low. Battery storage discharge can then be carried out when the price of the electricity is high or when the buildings' electricity demand exceeds the amount that the own renewable energy supply unit itself can offer. Energy storage solutions can partially substitute energy grid reinforcements required by increasing share of renewables in the grids. Due to an increase in grid-balancing need and a decrease in costs, use of energy storage technologies is expected to grow rapidly in the next few decades $[1,2,4,7,12,13]$.

Deregulation of the electricity market has increased the number of energy supply options belonging to a grid. Deregulation, together with economic steering and decreasing costs of renewables, has already resulted in a rapid increase of intermittent production in grids of some major European countries. Therefore, a balance of storage capacity, backup power, and interconnections between electricity grids needs to be maintained to ensure reliable electricity generation $[1,6,9,14]$.

Increased competition resulting from deregulation has lowered the energy fee component in the energy bill of a customer. However, increased demand to invest in networks and storage methods to maintain a reliable energy supply creates pressure to increase grid fees. To reduce consumption peaks in the grid, the grid companies are introducing new peak power fees. Energy bills' fixed charges are growing, which reduces consumers' control over savings [6,15-18].

Use of digital technologies has allowed energy utilities to change to dynamic pricing, which means that the price of electricity is defined based on the demand at that moment. Dynamic pricing together with bi-directional connections enables new kind of demand response measures. New solutions allow households' own electricity generation to be sold to the grid. In addition, deactivation of some devices is made possible during periods of peak electricity demand, reducing economic risks related to increasing peak power fees. Thus, smart technologies enable households to achieve economic benefits from the energy market by taking control of their energy consumption and providing their flexibility to the system $[2,5,8,16,19-22]$.

Energy-relevant investment decisions made by households constitute one of the top energy consumption sectors in Western countries [21]. Households, owning about $60 \%$ of the building stock in Finland, are important actors in the changing regional energy system [23]. Selection of the energy supply (heat and electricity) system for the building is the major energy-relevant investment decision [24]. Energy supply selection has a long-term economic impact on the economy of the households as it affects utilization costs of the building and its' resale value. Hence, the investments have to respond to future challenges related to changing operational environment [25].

The resident or the builder most often bases their energy-relevant investment decisions on the capital cost or operating expenses [26-28]. The payback period is often used to assess the feasibility of the investment, but it is not sufficient alone [29]. In order to improve the life cycle economy of the energy supply, the design has to accommodate technological, economic, and regulatory changes in operational environment over the long time. Feasibility assessments have to favour such energy supply solutions that respond to both present and future circumstances with a low risk of becoming prematurely obsolete [25]. The conventional feasibility assessment has to be expanded to cover new opportunities and risks related to changing operational environment.

This paper proposes an extension for feasibility assessment of residential energy (heat and electricity) supply solutions in an operational environment undergoing major changes. The aim of the paper is to point out the economic elements that need to be included in assessment to reveal opportunities and risks for life cycle economy of energy supply. The extended procedure brings up the profitability of "future proofed" more sustainable solutions with lower risks related to utilization 
costs and with improved resale value preservation. Specification of the operational environment, the feasibility assessment process and the required extension, based on the systematic literature study, contributes to the originality of this paper. The paper also gives suggestions on how the political decision-makers could use the procedure to align the economic steering mechanisms in support of low-carbon energy supply solutions. A net-zero energy single-family house in Southern Finland served as the pilot case to verify the procedure presented in this paper.

\section{Methodology}

The research identifies the extensions for the conventional feasibility assessment process of the residential energy supply solutions required by the changing operational environment. The required extensions were identified by studying the effect of the changing operational environment on the development of the path to a low-carbon society with literature, Figure 1.

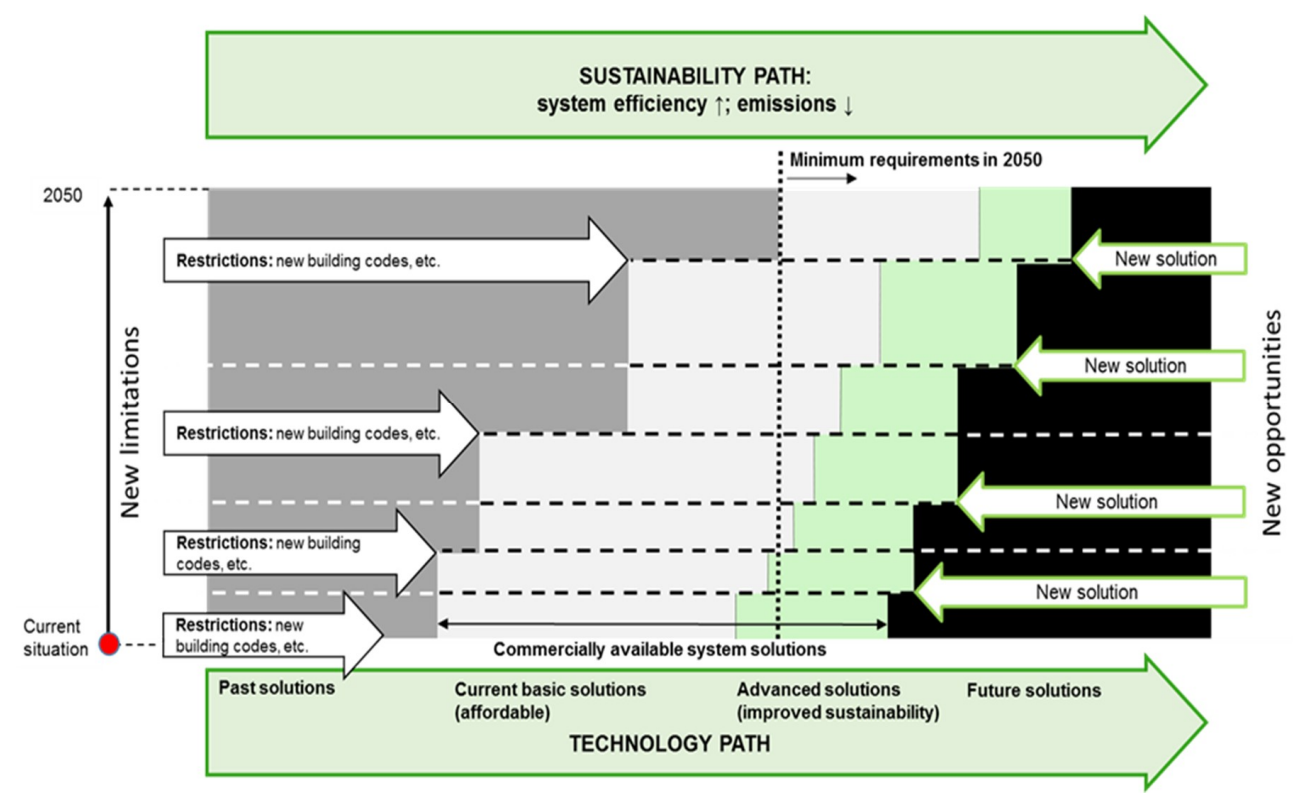

Figure 1. The changing operational environment plays a role in charting the path to a lowcarbon society.

When the builder considers the energy supply investment, there is a specific range of commercially available energy supply solutions available for that period (green area). This range includes the affordable solutions for that timeframe (light grey). More advanced and expensive technology is also available (light green). New restrictions continuously narrow the existing energy supply solutions' feasibility (dark grey area). These restrictions include the periodically updated national building codes and the potential economic steering, such as carbon tax [30-39]. Increased performance requirements related to the EU's 2050 low-carbon economy targets would most probably preclude most of 2018's basic energy supply solutions by 2050 (black dotted line). Technological development, new business service models and climate-oriented economic steering broaden the range of affordability, making advanced renewable and low-emission energy supply solutions more accessible (arrows on the right) $[4,5,7,12,19,30,31,40-43]$. The builder's challenge is to recognize which solutions are most feasible, as well as when it is most feasible to invest based on the building's life cycle.

A systematic literature review was conducted to identify which changes in the operational environment may have a considerable effect on the life cycle cost of energy supply solutions. The changes considered included new and emerging restrictions (national building codes, economic steering) and the new solutions (technological development, new business service models, and economic steering). The review recognized new relevant cost and income elements throughout a 
life cycle that must be included in feasibility assessment. The findings were structured and clarified into a decision support matrix presented later. In cooperation with the builder, the procedure was verified by identifying the optimal energy supply solution for the actual net-zero energy single-family house in Southern Finland.

\section{Results: Extended Feasibility Assessment Procedure for Residential Energy Supply Solutions}

The extended process for life cycle feasibility assessment of residential energy supply solutions is presented in Figure 2.

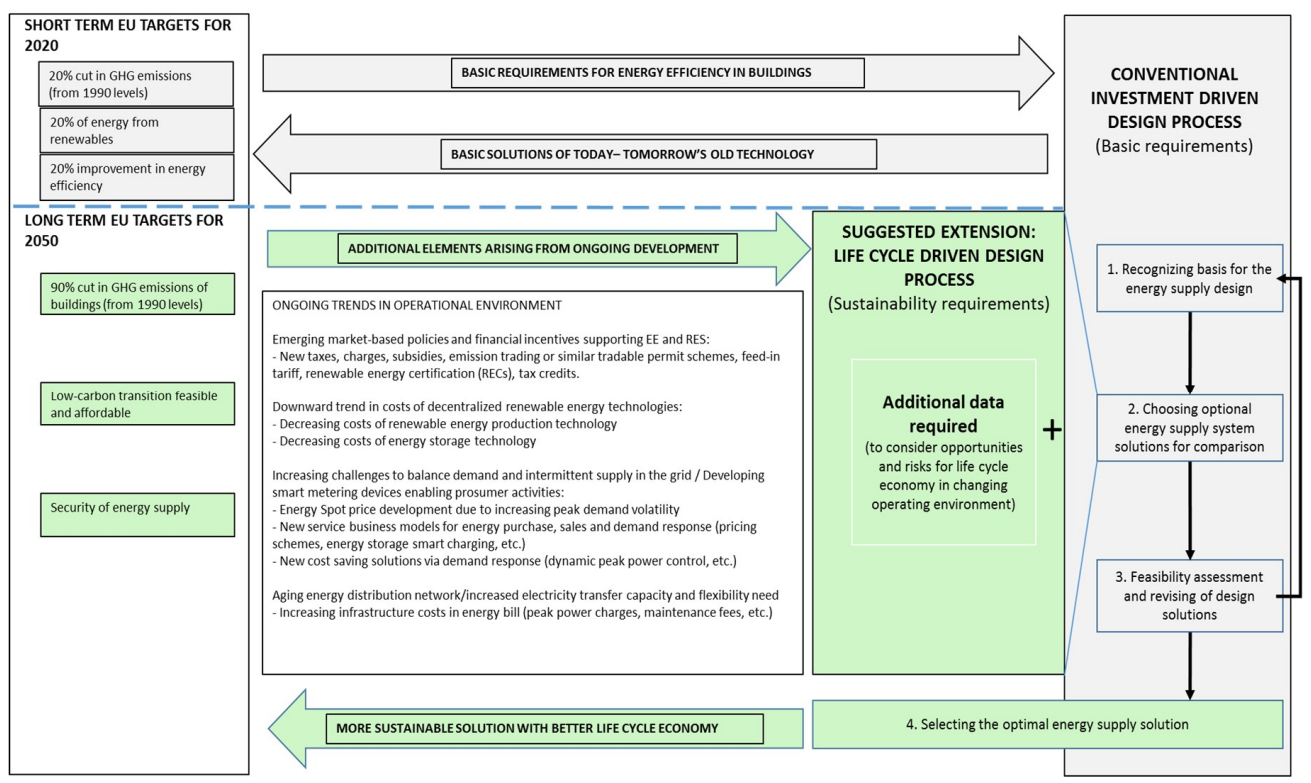

Figure 2. Extended procedure for life cycle feasibility assessment of residential energy supply solutions during design process.

The conventional design process of the energy supply is often driven by capital costs and relies on the national building codes of that time. While such solutions have the potential to satisfy the short-term EU climate targets, they often lack the level of performance required to reach the rigid long-term EU GHG emission reduction targets. Moreover, today's basic solutions most likely cannot provide preparedness for the economic opportunities and risks provided by the changing operational environment. The ongoing trends affecting the life cycle economy of the energy supply include the development of energy generation and network prices, the decreasing costs of decentralized renewable energy technologies (production and storages), and the emerging service business models and potential GHG reduction oriented economic steering, Figure 2. Unpreparedness for these changes might have unfavorable impacts on the life cycle economy of a building, including unexpectedly high operating expenses and low resale value.

Advanced renewable-based and low-carbon energy supply solutions allowing flexible energy use are required to achieve the 2050 low-carbon society targets of the EU. To bring up the life cycle feasibility of advanced solutions the economic comparisons of the conventional design process must be extended with additional elements that consider the ongoing development, Figure 2. A matrix in Table 1 provides a detailed description of the suggested extension to the design process. The matrix specifies the additional economic elements that need to be included in economic assessment, clarifying the extended life-cycle feasibility assessment procedure of the residential energy supply. Steps presented in the matrix refer to the steps of design process in Figure 2. Applying the matrix provides broader insights on the feasibility of energy supply solutions by revealing opportunities and risks for the life cycle economy in a changing operational environment. 
Table 1. Matrix to guide the extended life cycle feasibility assessment of energy supply solutions: A detailed description on the suggested extension.

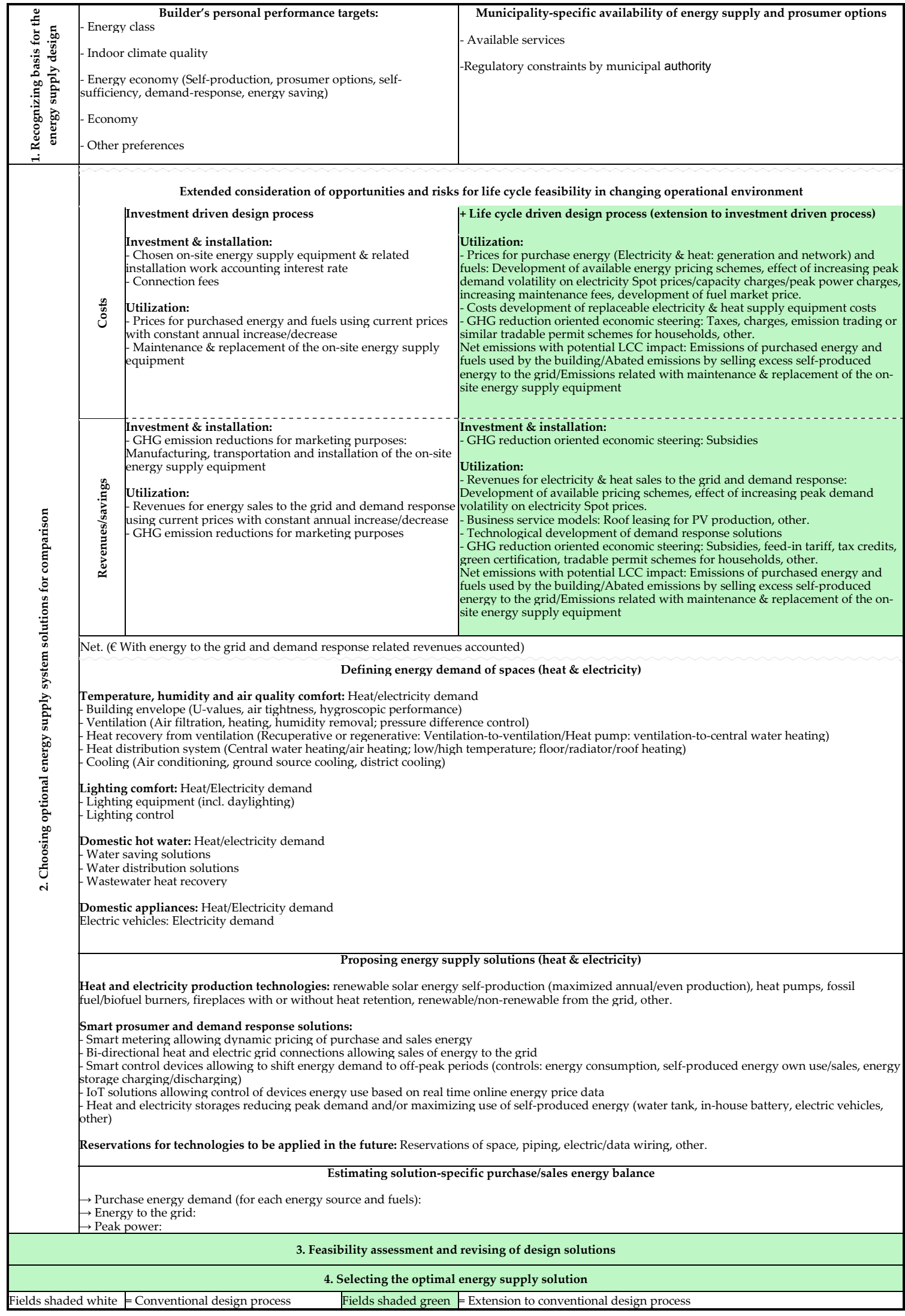




\subsection{Recognizing the Basis for the Energy Supply Design}

The energy supply's design process begins with identifying the builder's personal performance requirements. As the leader of the construction or renovation project, the builder makes the final decision on the energy supply solution. Here the builder's personal preferences regarding indoor climate quality, energy performance, economy, functionality, and climate impacts are decisive. To correctly establish project requirements the builder must be aware of the energy supply opportunities available locally. Consultants with expertise in the fields of construction technology, energy technology, local legislation, and the economy need to guide the builder when establishing the energy supply requirements $[23,24,44-47]$.

The minimum requirements for the performance (energy efficiency and indoor climate) of the building and energy supply as well the availability of services and prosumer options must be clarified with the help of the local municipal authority. As the body responsible for regional development, the municipal authority provides broad information on the requirements, restrictions, and licensing practices for energy supply. These include the requirements by national law, building standards, and local land use plans, as well as the restrictions for specific energy production technologies. Such restrictions include those for ground source (GS) heat due to groundwater areas. The municipal authority can also provide information on locally available energy networks, as well as on geological conditions to assess the suitability of ground source heat technology [23,32-39,48-53].

\subsection{Extended Consideration of Opportunities and Risks for Life Cycle Economy in a Changing Operational Environment}

Considering opportunities and risks for life cycle economy throughout design phase is fundamental to economically match the energy balance of the building with the balance of the supply network. The planner has to be aware about economic opportunities and risks before proposing any technical solutions. Highlighted with green, Table 1 specifies the additional life cycle cost elements to be included in economic consideration during design of energy supply. Future development of energy pricing, technological solutions, and economical steering mechanisms affect the long-term utilization economy and the preservation of the energy supply investment's value long-term.

Development of purchase energy (generation, network, and tax) prices greatly affects the feasibility of solutions aimed at energy conservation, energy use flexibility, and renewable energy self-production. Future energy bills are affected by increasing maintenance fees, available energy pricing schemes, and increasing peak demand volatility of electrical energy Spot prices and peak power charges. Revenue from energy sales defines the profitability of renewable energy self-production technologies, as well as the optimal sizing of production in relation to energy demand. Revenue from energy sales to the grid are affected by energy Spot price development along with the available energy sales pricing schemes. Development of Spot prices, peak power fees, and business service models will affect the feasibility of demand response solutions steering energy purchases and sales towards profitable energy market prices and reducing peak power demand [6,15-19,52-57].

The builder must be aware of the impact of potential low-carbon oriented economic steering on utilization costs. If introduced, carbon taxes, charges, subsidies, or tradable emission permit schemes for households will affect the profitability of the energy supply investment in favor of renewables and low-carbon solutions. Life cycle GHG emission reductions are commonly estimated for marketing purposes only. Extended consideration of life cycle economy must include net GHG emissions with the potential life cycle cost impact. These GHG include emissions of purchased energy and fuels used by the building, as well as abated emissions from selling excess self-produced energy to the grid [54,58-60].

The extended life cycle feasibility assessment requires estimation of the building's solution-specific energy balance, including purchase energy demand, peak power demand, and energy sales to the grid. The building's energy demand must be estimated based on the characteristics of the envelope, ventilation, cooling, domestic hot water, and electricity-consuming domestic appliances. To estimate 
purchase energy demand, peak power demand, and energy sales to the grid, the alternative energy supply solutions applied to match the heat and electricity energy balance of the building with the balance of the energy supply networks must be described. Accountable solutions include on-site heat and electric energy production installations, as well as grid supply solutions. In addition, the solutions improving life cycle economy through demand response need to be specified. Demand response solutions control energy consumption, sales, and storage reducing peak power demand. These include smart metering, bi-directional grid connections, energy storages, and electric vehicles as well as smart metering systems, IoT (Internet of Things) based devices, and the algorithms controlling the energy balance. [12,36,38-40,42,46,57].

The extended life cycle comparison of alternative energy supply design solutions is conducted with the estimated energy balance parameters. The optimal energy supply solution is selected based on comparison of solution-specific life cycle economies. The energy supply solutions can be iteratively modified if necessary to achieve the optimal match with the builders' preferences. Besides the energy supply, the other components of the building concept can be revised if the change improves the overall viability.

\section{Verification of the Procedure at the Pilot Case}

A new single-family house in Southern Finland (Figure 3) was used as a pilot case for verification of the procedure developed in this study. The case building is a hillside building with a basement floor. In this construction project, the builder, as an energy efficiency researcher, was aware of the new opportunities and risks related to a changing operational environment. The optional energy supply solutions for the case building were developed and compared using the extended feasibility assessment procedure presented.

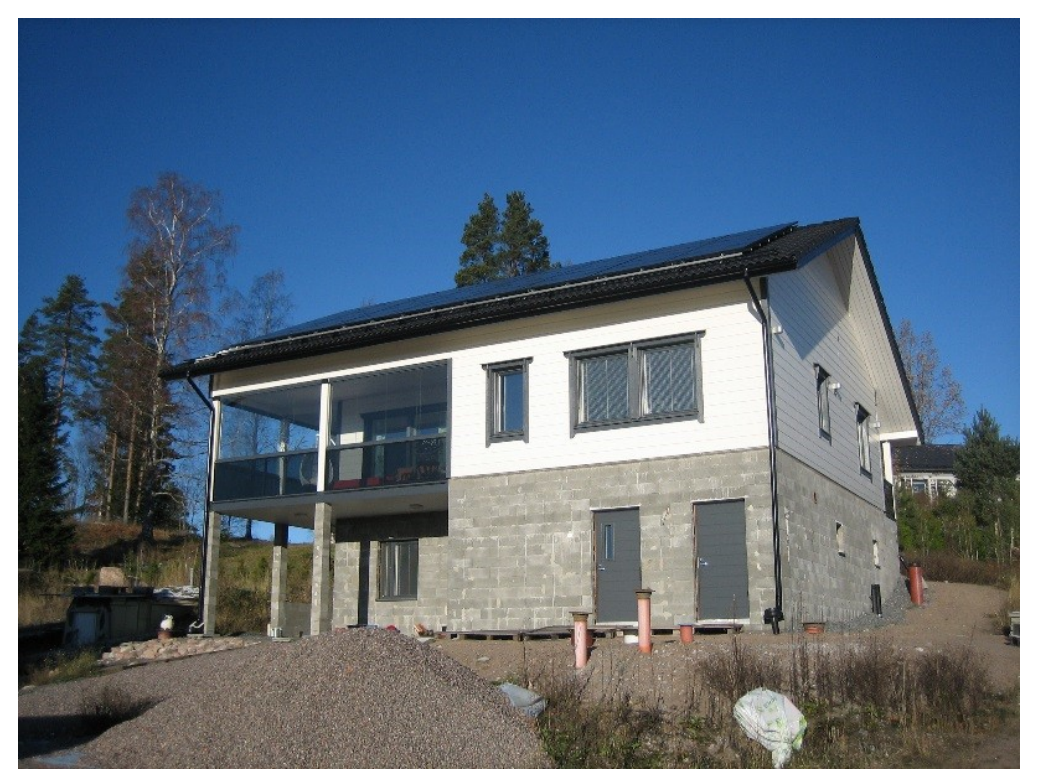

Figure 3. Case building (Photograph by Antti Kosonen, 2018).

\subsection{Recognizing Basis for the Energy Supply Design}

The builder minimized the building's operational costs and GHG emissions in order to improve investment's resale value in the changing operational environment. Minimizing purchase energy demand was targeted to manage the economic risk of uncertain energy price (generation, network and capacity) volatility in the future. The builder's goal was a net annual zero energy building with energy class A, a maximum calculated energy consumption of $79 \mathrm{kWh}_{\mathrm{E}} / \mathrm{m}^{2} \mathrm{a}$. Self-production and sales of renewable energy as well as demand response were desired in order to benefit from new and emerging 
prosumer business service models. Ensuring indoor climate quality was recognized as more important than minimization of space heating demand. The builder preferred simple and risk-free building envelope solutions with improved hygroscopic performance, airtightness, and long service life.

In Finnish conditions, achieving net annual zero building requires selling self-produced renewable electricity to the grid. The Nordic electricity market allows self-produced electricity to be sold to the grid with the Spot price. Self-produced heat to the grid is not yet commonly available for sale. Photovoltaic panels (PV) are the most practical solution for electricity self-production, since wind electricity production is not considered viable on a single-family house scale. Since district heating is not available at the location, the available means to produce the heat energy demand of the building are the electric grid, ground and air source heat, and solar energy. There are no regulatory or climatic restrictions for ground source heat or solar energy production.

\subsection{Defining the Energy Demand of Spaces}

Energy supply solutions defining energy demand of the building were proposed. Low-risk solutions providing high indoor climate quality with efficient use of energy and high energy self-sufficiency were pursued throughout the design of the building and the energy supply.

Solar electricity and ground source heat production potential were the main criteria for choosing the building's plot. Solar electricity production required high availability of solar irradiance on the plot throughout the day. The plot needed to allow positioning of the building, so that the roof panes would face south-north directions to achieve the optimal direction of the PV panels. Ability to utilize ground source heat was the prerequisite for the plot selection.

The builder chose a laminated log structure for the envelope of the aboveground living floor. The laminated log envelope, as a simple structure with high hygroscopic performance, is an efficient solution to manage the indoor climate quality risks related to the relative humidity [61]. Organic insulation materials between logs and vapor permeable paints were used to promote the structures' hygroscopic performance due to the ability of logs to balance short period relative humidity fluctuations. Industrially produced laminated logs have considerably reduced sinking characteristics compared to natural logs. Laminated logs are simple and long-lasting structures, which improve buildings' serviceability and service life. Log structures have low-carbon footprint due to wood's ability to capture atmospheric carbon for long periods. The improved air tightness achieved with industrially shaped laminated log, together with efficient insulation materials between logs and accurate installation minimizes the heat losses compared to natural log structure. Good overall air tightness of the envelope, measured after the construction to be $n 50=0.6 \mathrm{Vol} / \mathrm{h}$, fulfills the criteria of a passive house.

Due to the hillside plot, the basement floor envelope had to be built with insulated concrete block walls and ground supported floor with extruded polystyrene (XPS) insulation. Concrete with expanded polystyrene (EPS) insulation suits the builder's preferences well due to its good thermal insulation and favorable indoor climate impacts. The strong hygroscopic characteristics of concrete help to keep relative indoor humidity within the optimal level. The ability to store heat and coolness within the structural mass of concrete contributes to maintaining an even indoor temperature while reducing heating and cooling demand.

Reduced heat energy losses, hygroscopic performance, and solar energy production potential were pursued in roof structure design. Wood frame with $500 \mathrm{~mm}$ thick organic wood fiber insulation was chosen to promote the roof's hygroscopic performance. To keep the southern pane free for PV panels, the feedthrough holes for chimneys and the ventilation were positioned on the northern pane.

Window and door types with improved energy efficiency were chosen. The windows' directions (predominantly facing South) were optimized to promote passive solar heat gain during winter, while long eaves and a large balcony prevent direct sunshine in summer from reducing energy demand for cooling. The balcony's glazing reduces heat energy demand during winter. 
A ventilation machine equipped with a rotary heat exchanger with high annual efficiency of $75 \%$ was applied to minimize ventilation heat losses. To reduce the electric energy demand of air conditioning, the builder selected the ground source heat pump liquid-based heat exchanger which pre-cools or pre-heats supply air. After the heat recovery, the supply air is heated with the electric coil to required supply temperature. Filtration of supply air improves the indoor air quality.

For domestic appliances, the energy class A+ and higher was pursued to minimize electricity consumption. The house's lighting uses energy efficient LED technology with motion and illuminance control in the toilet and outdoors.

A central low-temperature water heating system with floor distribution provides even temperature profile indoors, comfortable floor temperature, and requires no space reservations for space heating radiators. Floor distribution allows storing heat in the structural mass of the floor plate smoothing heat demand peaks caused by daily outdoor temperature changes. Central water heating can link the variety of heat production and energy storage technologies, including ground source heat, solar thermal systems, district heating, and heat retention fireplaces. Circulation of domestic DHW (domestic hot water) is activated by the motion sensor in the toilet to quickly provide hot water while minimizing pumping energy and reducing the circulation loop's heat losses.

\subsection{Choosing Optional Energy Supply System Solutions for Comparison}

Four alternative energy supply solutions resulting with different purchase and sales energy balances were proposed for the case building:

Solution 1. Direct electric space heating with heat retention fireplaces.

Three fireplaces (fireplace, stove, baking oven), used as a supplementary heating system, increase flexibility of purchase energy use while burning renewable wood to reduce heating demand peaks and during high electricity market prices. Recovering stoves' heat to central heating water further balances energy use. This is the basic energy supply solution currently common for the single-family house in Finland. This solution was used as a reference solution in comparison of life cycle costs and GHG emissions.

Solution 2. Solution $1+$ the ground source heat pump with the heat output of $6 \mathrm{~kW}$.

The future risks related with energy market development are handled by reducing purchase energy demand with a heat pump. Providing heat throughout the year and scaling down electricity purchase demand peaks, this technology mitigates the risks related with increasing peak power charges. Heat retention fireplaces like those in solution 1 are used as a supplementary heating system.

Solution 3. Solution $2+$ the PV panels of total $5 \mathrm{~kW}_{\mathrm{p}}$.

Renewable energy self-production further reduces GHG emissions and the economic risks related with the development of future purchase energy costs. Solar PV panels with typical scaled to electricity demand size in Finland of $5 \mathrm{~kW}_{\mathrm{p}}$ on the roof of the building increase energy self-sufficiency. Bi-directional grid connection enables benefits of selling the surplus self-produced energy to the grid, as well as from emerging demand response service business models.

Solution 4. Solution $2+$ the PV panels of total $21.1 \mathrm{~kW}_{\mathrm{p}}$.

This solution pursues net-positive energy building. All available roof space on the building and the garage is used for the $21.1 \mathrm{~kW}_{\mathrm{p}}$ PV panels' installation. Large size PV panels facing three general directions (East, South, and West) allow solar electricity production even during low radiation periods (cloudy weather, low radiation angle) which reduce purchase demand of more expensive grid electricity.

Besides the proposed heat and electricity production alternatives, all energy supply solutions include following demand response components and reservations: 
Automated energy use control allows flexible operation of the ground source heat pump, which reduces peak electricity demand and increasing energy self-sufficiency. Automation steers heat production towards the periods with low Spot-electricity price and high PV electricity production. Possibility to steer energy use of domestic appliances and sauna stove also exists.

A dual-level $750 \mathrm{~L}$ hot water storage tank serves space heating and DHW heat purposes. The storage was sized to provide the required DHW for a family of four persons for one day with a single charge. During summer, the storage heats the DHW with solar electricity via a ground source heat pump, thereby reducing the demand for electricity purchases. In addition, the structural mass of buildings, including concrete blocks, fireplaces, and chimneys, performs as heat storage, balancing heat loads and reducing electricity demand peaks.

Data wire between the garage and the main building allows enabling smart charging of the electric battery storage and electric vehicle, if these will be introduced in the future. Also, lead-through reservations for power cables makes future introduction of new technologies easier. Introduction of electric storage and an electric vehicle would allow an increase in the user's own use of self-produced cheaper renewable electricity.

\subsection{Feasibility Assessment and Revising of Design Solutions}

Life cycle costs and GHG emissions were estimated for all the alternative energy solutions. The life cycle of the building was considered to be 30 years. The initial data used in this feasibility assessment is presented in Table 2.

Investment and installation costs of the chosen energy production and supply solutions were estimated using component-specific average costs in Finland, as shown in Table 2. The cost estimation included the energy equipment: the GS heat pump unit, GS borehole, PV panels, PV inverter, heat storage tank, heat retention fireplaces, and central water heating system with floor distribution. The total cost included the value-added tax and the 20 years average Euribor-based interest rate of two percent. The local energy utility's electric grid connection fee was also considered. Greenhouse gas emissions produced during the manufacturing and installation of the equipment are considered equal for all the examined solutions. Therefore, these emissions do not affect the comparison and were not considered in this assessment in order to simplify the demonstrative calculations.

The estimation of the energy system's use-related costs included the costs of purchased energy, revenues from surplus energy sales and equipment maintenance. Estimation of costs and revenues was based on the on the average Finnish Spot and transmission prices for 2016 including all taxes. The electric energy price was assumed to increase at an average rate of three percent annually, a Finnish decadal average. Annual increase in electricity transmission fees was assumed to be 4.6 percent, a Finnish decadal average. The case building's energy demand was assumed to be $22,400 \mathrm{kWh} / \mathrm{a}$ as stated in the energy certificate. Solution-specific purchased and sold energy estimates were concluded relying on the actual measured data during one year of operation of the solution 4. Annual reduction in solar PV panels production performance was assumed to be $0.5 \% / \mathrm{a}$. Suggested maintenance and replacement costs were defined with the average cost of the action and its estimated number of occurrences during the life cycle of the building. Average component-specific service life and average costs of the component and its replacement work in Finland were applied.

Greenhouse gas emissions occurring during use of the building were identified to allow consideration of the potential impact of low-carbon oriented economic steering on life cycle economy. Use emissions were estimated using the energy source-specific emission factors and the suggested purchase energy and fuel demands. For the grid electricity the emission factor for the electricity production in Finland, $175.1 \mathrm{~g}\left(\mathrm{CO}_{2} \mathrm{e}\right) / \mathrm{kWh}$, was utilized. Burning of firewood, as a renewable energy source, was assumed carbon neutral. Self-produced solar electricity sold to the grid lead to abatement of the GHG emissions elsewhere in the grid. Abated emissions related to selling surplus self-produced renewable energy to the grid are reduced from the emissions of the purchased energy. 
Table 2. Initial data used in feasibility assessment of energy supply solutions for the case building.

\begin{tabular}{|c|c|c|c|c|c|}
\hline \multirow{2}{*}{ Life Cycle } & \multirow{2}{*}{\multicolumn{2}{|c|}{$30 \mathrm{a}$}} & \multicolumn{3}{|c|}{ Life Cycle Costs } \\
\hline & & & & Energy Costs & \\
\hline Calculated energy demand (heat \& electricity): & $22,400 \mathrm{kWh} / \mathrm{a}$ & Energy certificate & Electricity price (Spot, incl. Tax) & $0.04 € / \mathrm{kWh}$ & Nordpool 2016 average [62] \\
\hline & $12,000 \mathrm{kWh} / \mathrm{a}$ & Energy certificate & Annual electricity price increase & $3 \%$ & Finnish 10 year average [62] \\
\hline \multirow{2}{*}{ Energy produced by fireplaces } & $3000 \mathrm{kWh} / \mathrm{a}$ & Derived from the energy balance of solution 4 & Electricity transmission price (incl. Tax) & $0.06 € / \mathrm{kWh}$ & 2016 average [62] \\
\hline & Solution 4 (first year) & & $\begin{array}{l}\text { Annual electricity transmission } \\
\text { price increase }\end{array}$ & $4.6 \%$ & Finnish 10 year average [16] \\
\hline Solar electricity production & $16,500 \mathrm{kWh} / \mathrm{a}$ & Measured & Firewood price & $0.06 € / \mathrm{kWh}$ & [63] \\
\hline Solar electricity for own use & $2608 \mathrm{kWh} / \mathrm{a}$ & Measured & \multirow{2}{*}{\multicolumn{3}{|c|}{ Capital costs of equipment with installation included (VAT 0\%) }} \\
\hline Purchase electricity & $4850 \mathrm{kWh} / \mathrm{a}$ & Measured & & & \\
\hline Electricity sale & $13,400 \mathrm{kWh} / \mathrm{a}$ & Measured & Ground source heat pump & $6023 €$ & {$[64,65]$} \\
\hline \multirow{2}{*}{ Solar electricity own use } & $2600 \mathrm{kWh} / \mathrm{a}$ & \multirow[t]{2}{*}{ Measured } & Borehole & $24 € / \mathrm{m}$ & [66] \\
\hline & Solution 3 (first year) & & $\begin{array}{l}\text { PV panels } \\
\text { Jnyerter }\end{array}$ & $\begin{array}{l}1270 € / \mathrm{kW}_{\mathrm{p}} \\
80 € / \mathrm{kW}\end{array}$ & {$[67]$} \\
\hline Solar electricity production & $4000 \mathrm{kWh} / \mathrm{a}$ & Scaled from measured & Fireplaces (baking oven) & $5900 € /$ pcs & {$[64,65]$} \\
\hline Solar electricity for own use & $2400 \mathrm{kWh} / \mathrm{a}$ & Scaled from measured & Fireplaces (stove) & $4200 € /$ pcs & {$[64,65]$} \\
\hline Purchase electricity & $5000 \mathrm{kWh} / \mathrm{a}$ & Scaled from measured & Central water heating system & $18.91 € / \mathrm{brm}^{2}$ & {$[64,65]$} \\
\hline \multirow{3}{*}{ Solar electricity own use } & $1500 \mathrm{kWh} / \mathrm{a}$ & & Heat storage tank & $2280 € / \mathrm{pcs}$ & [66] \\
\hline & \multirow{2}{*}{$2400 \mathrm{kWh} / \mathrm{a}$} & \multirow{2}{*}{ Scaled from measured } & Electric grid connection fee & $2350 €$ & [68] \\
\hline & & & VAT & $24 \%$ & Finnish VAT in 2018 \\
\hline \multirow{2}{*}{ Annual reduction in PV production performance } & \multirow[t]{2}{*}{$0.5 \%$} & \multirow[t]{3}{*}{ [69] } & \multirow{4}{*}{\multicolumn{2}{|c|}{$\begin{array}{c}2 \% \\
\text { Maintenance costs of equipment: } \\
62 € / \mathrm{a} \\
\text { Equals to capital costs }\end{array}$}} & \multirow{4}{*}{$\begin{array}{c}\text { Euribor } 20 \text { year average } \\
\text { (Average by local service providers) } \\
\text { VAT } 24 \%\end{array}$} \\
\hline & & & & & \\
\hline \multirow{2}{*}{\multicolumn{3}{|c|}{$\begin{array}{l}\text { GHG emissions } \\
\text { Energy source-specific GHG emission factors (gCO2ekv./kWh) }\end{array}$}} & & & \\
\hline & & & & & \\
\hline $\begin{array}{l}\text { Electricity (Purchase) } \\
\text { Electricity (Self-produced PV) }\end{array}$ & $\begin{array}{c}175.1 \\
0\end{array}$ & \multirow{4}{*}{$\begin{array}{c}\text { Finnish grid average [70] } \\
\text { Renewable source } \\
{[70]} \\
\text { Renewable source, fuel production emissions } \\
\text { not considered }\end{array}$} & \multicolumn{3}{|c|}{ Technical service life of equipment (years): } \\
\hline Electricity sales to the grid (Abated emissions) & 175.1 & & Ground source heat pump unit & $25 \mathrm{a}$ & {$[23,71]$} \\
\hline \multirow[t]{2}{*}{ Firewood } & 0 & & Borehole & $100 \mathrm{a}$ & [23] \\
\hline & Other GHG emissions & & $\begin{array}{l}\text { PV panels } \\
\text { Inverter }\end{array}$ & $\begin{array}{l}30 a \\
15 a\end{array}$ & {$[23]$} \\
\hline Manufacturing of equipment & Not considered & Assumed equal for all examined solutions & Fireplaces/chimneys & 50 a & {$[64,65,73]$} \\
\hline Installation of equipment & Not considered & Assumed equal for all examined solutions & Central water heating system & $60 \mathrm{a}$ & {$[64,65,73,74]$} \\
\hline Maintenance of equipment & Not considered & Assumed equal for all examined solutions & Heat storage tank & 30 a & {$[66,73,74]$} \\
\hline Emissions of fuel production chain & Not considered & & & & \\
\hline
\end{tabular}




\subsection{Comparison of the Alternative Energy Solutions}

Applying the extended feasibility assessment procedure, the life cycle costs and GHG emissions were estimated for each considered energy supply solution, Table 3.

Based on the conducted feasibility assessment the builder chose solution 4, allowing the best preparedness for future economic risks in addition to the greatest (life cycle net negative) GHG emission reductions. The choice is justified by the fact that solution 4 is the only one capable of satisfying the builder's strict personal performance requirements. Achieving the indoor climate quality benefits of the log structures and the high level of energy self-sufficiency requires efficient energy supply with renewable energy self-production. Ground-source heat technology, solar electricity self-production and demand response solutions efficiently reduce utilization costs by cutting peak power demand and increasing energy self-sufficiency. The PV system, sized beyond buildings' own electricity demand and facing three general directions, efficiently reduces utilization costs by cutting purchase electricity demand. Such a system has made it possible to replace more expensive grid electricity with cheaper self-produced electricity even during low radiation periods. The net annual zero energy target was exceeded due to selling the surplus self-produced electricity to the grid above the purchase energy demand. The energy certification provided the building the highest energy class, that of $A$, satisfying the builder's goal. Due to net-negative GHG emissions $\left(-42,300 \mathrm{tCO}_{2} \mathrm{e}\right)$, the solution efficiently mitigates the risk related with the potential carbon-neutrality oriented economic steering. Improved resale value, risk preparedness, and opportunities related to future energy pricing and economic steering are provided with considerably lower life cycle costs $(115,000 €)$ compared to the reference solution $(146,500 €)$.

The introduction of a ground source heat pump, as in solution 2, allows reduction of the life cycle cost of electric heating by $34,000 €$. A ground source heat pump reduces the case's life cycle electricity purchase demand, to less than half $(224,000 \mathrm{kWh} /$ life cycle) compared to the direct electric heating, reference solution $(581,500 \mathrm{kWh} /$ life cycle). However, the ground source heat pump can provide only limited energy use flexibility and GHG emission reductions with no renewable energy self-production. The addition of five $\mathrm{kW}_{\mathrm{p}}$ solar PV installations with the prosumer interface (solution 3) further reduces annual purchase electricity demand and halves the life cycle GHG emissions of the ground-source heat-only solution, resulting in $5050 \mathrm{kWh} / \mathrm{a}$ and $19,850 \mathrm{t}\left(\mathrm{CO}_{2} \mathrm{e}\right)$ respectively. Solution 3 provides the lowest life cycle costs $(105,300 €)$ among the compared solutions. However, this size of PV panels does not allow the magnitude of energy sales to the grid required to achieve the net annual zero energy target of the builder. Increasing the size of the solar panel installation to $21.1 \mathrm{~kW}_{\mathrm{p}}$ (solution 4) provides more significant economic risk mitigation and resale value maximization in the future. An electricity Spot price above $5.8 €$ cent $/ \mathrm{kWh}$ (currently $4 €$ cent $/ \mathrm{kWh}$ ) is sufficient to make solution 4 the most feasible solution in terms of life cycle costs.

The builder decided to not to invest in electric energy storage or in an electric vehicle at this point. The costs of these technologies are currently still rather high, although they are quickly and constantly lessening. Established reservations will make introducing the batteries and electric vehicle smart-charging easy when the investment becomes more feasible.

With no personal expertise in energy market and climate change abatement, the grass-roots builder might not currently consider the advanced solution 4 feasible. If the local climate strategy relies on more advanced and sustainable solutions, economic support measures are required to increase introduction of these solutions now. The economic steering measures tailored to remove the possible profitability gap of low-emission solutions are needed. The market-based policy measures can include taxes, tax relief, subsidies, reduction of environmentally harmful subsidies, feed-in tariffs, and emission trading schemes for households. 
Table 3. Case application of the extended life cycle feasibility assessment.

\begin{tabular}{|c|c|c|c|c|c|}
\hline 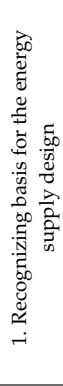 & $\begin{array}{l}\text { Builder's pe } \\
\text { Energy class: Net annual zero en } \\
\text { Indoor climate quality: High ind } \\
\text { materials (Class M1), vapor pern } \\
\\
\text { Economy: Minimizing operation } \\
\text { - Preparation for risks related to fu } \\
\text { energy demand with renewable } \\
\text { - Preparation for potential opport } \\
\text { low-carbon energy supply soluti } \\
\text { Other preferences: Reduction of } \\
\text { air tightness, heat capacity. }\end{array}$ & $\begin{array}{l}\text { sonal performance targets (Single fa } \\
\text { rgy, energy certificate class A. } \\
\text { or climate quality with ventilation air } \\
\text { rability of structures. } \\
\text { l costs and ensuring resale value of } t \\
\text { ture energy pricing: Reduction of pea } \\
\text { nergy self-production, energy efficier } \\
\text { nities risks related to low-carbon or } \\
\text { ns and sales of RE to the grid. } \\
\text { HG emissions, simple and safe struct }\end{array}$ & $\begin{array}{l}\text { nily hillside log house): } \\
\text { filtration, cooling, low-emission furniture and } \\
\text { e investment } \\
\text { power demand and minimization of purchase } \\
\text { solutions and demand response solutions. } \\
\text { nted economic steering: Utilization of RE and } \\
\text { es, long service life, hygroscopic performance, }\end{array}$ & $\begin{array}{l}\text { Municipality-specific availa } \\
\text { Available services: } \\
\text { Electric grid available } \\
\text { Sales of electricity to the grid available } \\
\text { Prosumer options: } \\
\text { No restrictions for ground source (GS) hea } \\
\text { No restrictions for solar electricity and hea } \\
\text { No restrictions for wind electricity }\end{array}$ & nergy supply and prosumer options: \\
\hline \multirow{4}{*}{ 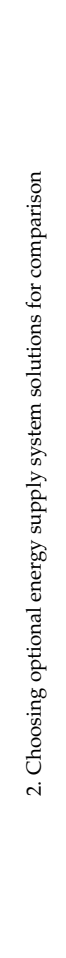 } & \multicolumn{5}{|c|}{$\begin{array}{l}\text { concrete with } 200 \mathrm{~mm} X \mathrm{XS} \text { insulation, } \mathrm{U} \text {-value } 0.15 \mathrm{~W} /\left(\mathrm{m}^{2} \mathrm{~K}\right) \text {. Wood framed roof: } 500 \mathrm{~mm} \text { wood fiber insulation wit } \\
\text { winter, U-value } 0.8-0.82 \mathrm{~W} /\left(\mathrm{m}^{2} \mathrm{~K}\right) \text {. Doors: } \mathrm{U}-\mathrm{v} \text {-value } 0.6-0.75 \mathrm{~W} /\left(\mathrm{m}^{2} \mathrm{~K}\right) \text {. Long eaves and large glazed balcony to prev } \\
\text { promoting hygroscopic performance of structure. } \\
\text { - Ventilation: Fan assisted ventilation (inlet/outlet) with rotary heat exchanger (annual average heat recovery efficien } \\
\text { - Heat distribution system: Central low-temperature water heating with floor distribution allowing operation of } \mathrm{GS} \mathrm{h} \\
\text { Cooling: Air conditioning (AC) } \\
\text { Lighting comfort: Energy efficient LED lighting. Motion and illuminance controlled outdoor and toilet lighting. } \\
\text { Domestic appliances: Energy efficient appliances with minimum A+ energy class. } \\
\rightarrow \text { Calculated energy demand (heat \& electricity): } 22,400 \mathrm{kWh} / \mathrm{a}\end{array}$} \\
\hline & \multicolumn{5}{|c|}{$\begin{array}{l}\text { Demand response solutions (common to all proposed solutions): } \\
\text { - Energy storage: Two level heat storage water tank ( } 750 \text { l) (lower part } \\
\text { block structures of building. } \\
\text { - Smart energy use control: Automation allowing scheduling energy } \\
\text { Reservations for technologies to be applied in the future: Data wir } \\
\text { allow increasing own use of self-produced cheap renewable electricit } \\
\text { Heat and electricity production technologies: }\end{array}$} \\
\hline & & \begin{tabular}{|l|} 
Solution 1 (reference): \\
Direct electric heating \\
Three heat retention fireplaces
\end{tabular} & $\begin{array}{l}\text { Solution 2: Solution 1+ } \\
\text { Ground source heat pump }(6 \mathrm{~kW})\end{array}$ & $\begin{array}{l}\text { Solution 3: Solution } 2+ \\
\text { Solar PV panels }\left(5 k \mathrm{~W}_{\mathrm{p}}\right) \\
\text { Prosumer's bi-directional grid connection }\end{array}$ & $\begin{array}{l}\text { Solution 4: Solution } 2+ \\
\text { Solar PV panels }\left(21.1 \mathrm{~kW}_{\mathrm{p}}\right) \\
\text { Prosumer's bi-directional grid connection }\end{array}$ \\
\hline & 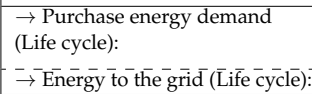 & $\begin{array}{l}\text { Electricity } 581,500 \mathrm{kWh} \text {, Firewood } \\
90,000 \mathrm{kWh}\end{array}$ & $\begin{array}{l}\text { Electricity } 224,000 \mathrm{kWh} \\
\text { Firewood } 90,000 \mathrm{kWh}\end{array}$ & $\begin{array}{l}\text { Electricity } 155,500 \mathrm{kWh}, \\
\text { Firewood } \\
\text {-Electricitity } 42,500 \mathrm{kWh} \\
42,500 \overline{\mathrm{k}} \overline{\mathrm{h}} \\
\end{array}$ & $\begin{array}{l}\text { Electricity } 151,000 \mathrm{kWh}, \\
\text { Firewood } 90,000 \mathrm{kWh} \\
\text { Electricity } 392,000 \overline{\mathrm{kWh}}^{-}\end{array}$ \\
\hline
\end{tabular}


Table 3. Cont

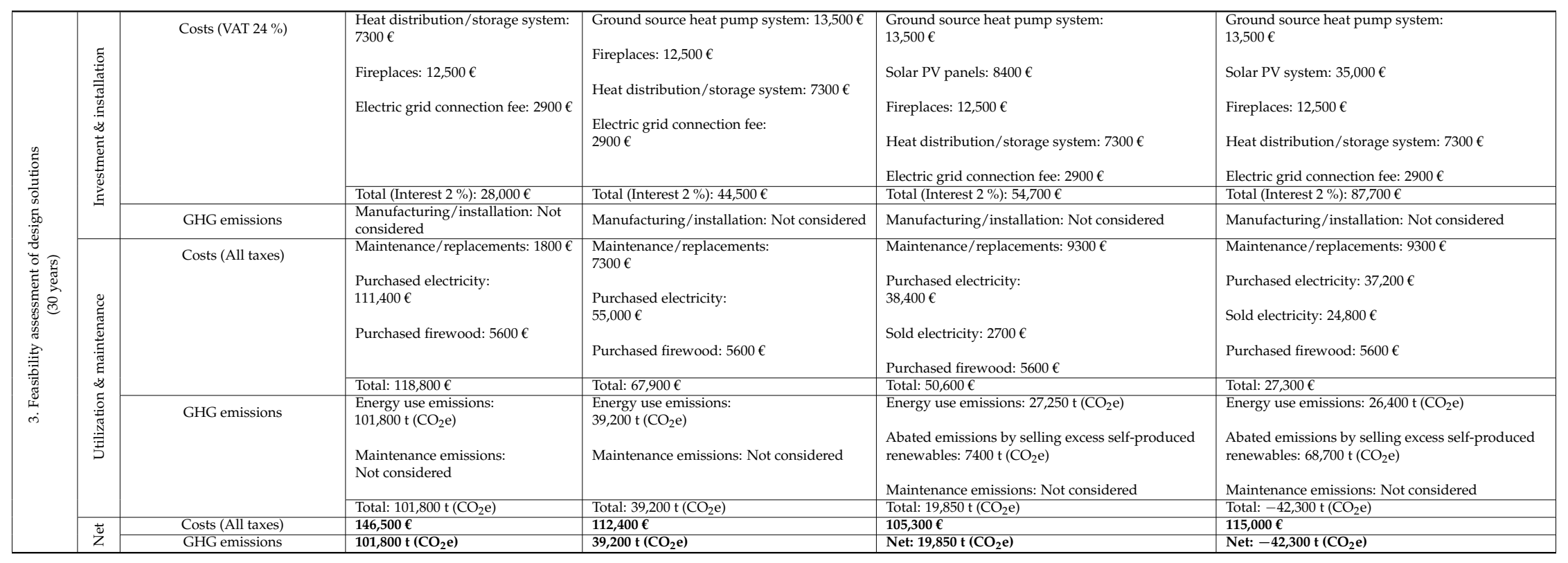




\section{Discussion and Conclusions}

This paper presents the extended feasibility assessment procedure for residential energy supply solutions in an operational environment undergoing major changes. The procedure provides guidance for inclusion of the novel economic elements into feasibility assessment required to evaluate the risks and the opportunities for life cycle economy of the energy supply. The proposed expansion of conventional feasibility assessment covers available advanced technological and service solutions, future development of energy pricing, and potential GHG reduction oriented economic steering. Applied during the design of energy supply, the extended procedure brings up the profitability of sustainable "future proofed" solutions with lower risks related to utilization costs and with improved resale value preservation.

The verification showed that additional capital investment in many advanced sustainable technologies is currently feasible for households similar to the pilot case. Technologies such as ground source heat pump, solar electricity self-production, and multiple solutions increasing efficiency of energy use are feasible if electricity price continue to grow. Figure 4 demonstrates how life cycle feasibility of the examined energy supply solutions is affected in different development scenarios of electricity Spot and transmission prices. Maximizing the size of PV installations is feasible as it efficiently mitigates the risk of further growth of purchase electricity costs. Larger PV systems allow replacing higher amount of expensive purchase electricity with cheaper self-produced energy even during low radiation periods. An annual electricity Spot price increase rate of $6 \%$ is enough to make solution 4 the most feasible, Figure 4 . Also, transmission prices rising at the rate of $6 \%$ annually make solar energy self-production solutions the most feasible. Electric battery storages and electric vehicles, allowing a user to increase their own use of cheaper self-produced electricity, will soon become feasible due to reducing capital costs and improving performance. Thus, it is worthwhile to prepare for future introduction of such technologies with space and technological reservations. Increasing electricity peak power fees and Spot price volatility improve feasibility of demand-response solutions. The emission trading scheme or similar, if introduced for households, would make profitable to maximize the size of the PV panel systems allowing emission abatement through energy sold to the grid. Basic solutions of today, such as the reference solution 1 , do not provide sufficient preparedness for the future economic risks and opportunities resulting in higher life cycle costs and potentially lower resale value.

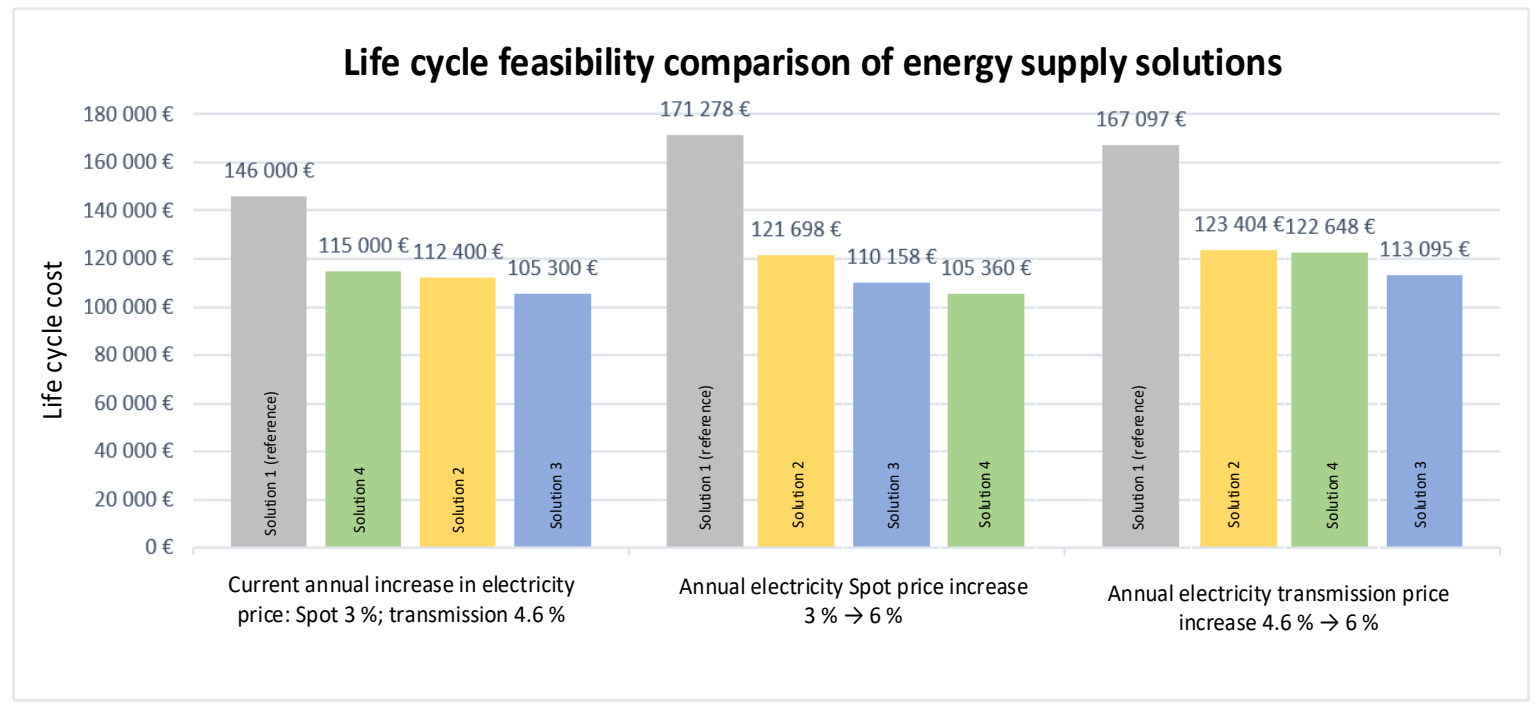

Figure 4. Life cycle feasibility comparison of energy supply solutions.

The verification demonstrated that the procedure provides new insights on the economy and the climate implications of the optional energy solutions even with the basic calculations. 
Supplemented with more detailed and precise initial data and advanced modelling software, the procedure can provide even deeper information for comparisons with further increased reliability. Applying the actual data, if available, instead of average values would increase the reliability of the assessment results.

The procedure allows assessing feasibility of the optional energy supply solutions for a specific building in a certain area. Feasibility assessment can include a range of the location-specific initial data. Location-specific data applied in this procedure include local renewable energy availability, regulations, availability of services, energy prices, equipment and labor costs, economic steering, etc. Utilization of location-specific data naturally affect the generalizability of the results.

Conducting the life cycle feasibility assessment requires making assumptions regarding the future development of heat and electricity costs. Applied assumptions regarding future energy fees, transmission fees, peak power fees, energy taxation, and GHG reduction oriented economic steering strongly affect the outcome of the life cycle feasibility assessment. Since the future development of the energy-related cost elements is never certain, the results of assessment unavoidably include a certain subjectivity. Studying different potential development scenarios of uncertain future cost elements will help to understand the risks and opportunities for life cycle economy more broadly.

The procedure can be applied for both the new buildings and the renovation projects comprising changes in the energy supply. Besides the residential buildings, the same economic evaluation principle is applicable for objects of different purpose and size.

The calculation processes of the suggested procedure require certain professional expertise in the field of energy efficiency, economy, and local regulations. A professional energy consultant can use the procedure as a checklist to recognize what elements it is relevant to include into feasibility assessment of energy supply method. Conducting the analysis presented in this paper can therefore create a demand for new specialized consulting services necessitating thorough knowledge of local conditions. This can create new business opportunities and local jobs.

The pursuit of GHG emission reduction cannot be left to residential builders only. If LCC analysis results reveal that solutions reducing GHG emissions are not economically sustainable, this should send a message to political decision-makers to realign the economic steering mechanisms. Economic steering measures should be established to direct the market towards sustainability. In addition, national building codes must be developed further to support the low GHG energy supply solutions. Future research should include identification of optimal steering mechanisms.

Author Contributions: Conceptualization, M.V., K.G., M.L. and R.S.; Methodology, M.L.; Validation, M.V. and A.K.; Investigation, M.V. and K.G.; Data Curation, A.K.; Writing-Original Draft Preparation, M.V.; Supervision, M.L. and R.S.; Funding Acquisition, R.S.

Funding: This work has been carried out partly in the project HEMU: The possibilities and threats of renewable decentralized energy funded by the Finnish Government, which is gratefully acknowledged.

Conflicts of Interest: The authors declare no conflict of interest.

\section{References}

1. Bloomberg. New Energy Outlook 2017. Available online: https://about.bnef.com/new-energy-outlook/ (accessed on 12 March 2018).

2. IEA (International Energy Agency). World Energy Outlook. 2017. Available online: https://www.iea.org/ weo2017/ (accessed on 12 March 2018).

3. IEA. Renewables. 2017. Available online: https://www.iea.org/renewables/ (accessed on 15 March 2018).

4. IRENA (International Renewable Energy Agency). Turning to Renewables: Climate-Safe Energy Solutions. Available online: http://irena.org/-/media/Files/IRENA/Agency /Publication/2017/Nov / IRENA_Turning_to_renewables_2017.pdf (accessed on 15 March 2018).

5. WWF (World Wide Fund for Nature). Megatrends in the Global Energy Transition. WWF Germany and LichtBlick SE. 2015. Available online: https:/ / energiewendebeschleunigen.de/Downloads/151201_ Megatrends_der_Energiewende_EN.pdf (accessed on 7 May 2018). 
6. IEA (International Energy Agency). World Energy Investment. 2017. Available online: https://www.iea. org/publications/wei2017/ (accessed on 16 March 2018).

7. IRENA. Electricity Storage and Renewables: Costs and Markets to 2030. Available online: http:/ / www.irena. org/-/media/Files/IRENA/Agency/Publication/2017/Oct/IRENA_Electricity_Storage_Costs_2017.pdf (accessed on 20 March 2018).

8. Niemelä, T. Cost-Optimal Renovation of Residential, Educational and Office Buildings in Finnish Climate toward Nearly Zero-Energy Buildings. Aalto University Publication Series DOCTORAL DISSERTATIONS 2018, 15/2018. Available online: https://aaltodoc.aalto.fi/handle/123456789/29635 (accessed on 9 February 2018).

9. Schirone, L.; Pellitteri, F. Energy policies and sustainable management of energy sources. Sustainability 2017, 9, 2321. [CrossRef]

10. TSE (Toulouse School of Economics). Negative Prices for Electricity. Available online: https://www.tse-fr. eu/negative-prices-electricity (accessed on 15 March 2018).

11. Milstein, I.; Tishler, A. Can price volatility enhance market power? The case of renewable technologies in competitive electricity markets. Resour. Energy Econ. 2015, 41, 70-90. [CrossRef]

12. EC (European Commission). Energy Storage: The Role of Electricity. Available online: https:// ec.europa. eu/energy/sites/ener/files/documents/swd2017_61_document_travail_service_part1_v6.pdf (accessed on 31 February 2018).

13. Koskinen, O.; Breyer, C. Energy storage in global and transcontinental energy scenarios: A critical review. Energy Procedia 2016, 99, 53-63. [CrossRef]

14. IPCC. Special Report on Renewable Energy Sources and Climate Change Mitigation. Available online: http:/ / www.ipcc-wg3.de/report/IPCC_SRREN_Ch08.pdf (accessed on 15 March 2018).

15. ACEEE (American Council for an Energy-Efficient Economy). Some Utilities Are Rushing to Raise Fixed Charges. That Would Be Bad for the Economy and Your Utility Bill. Available online: http: / / aceee.org/ blog/2014/12/some-utilities-are-rushing-raise-fixe (accessed on 20 March 2018).

16. Pereira, R.; Figueiredo, J.; Melicio, R.; Mendes, V.M.F.; Martins, J.; Quadrado, J.C. Consumer Energy Management System with Integration of Smart Meters. Energy Rep. 2015, 1, 22-29. [CrossRef]

17. Johnson, E.P.X.; Oliver, E. Renewable energy and wholesale electricity price variability. In IAEE Energy Forum; First Quarter. International Association for Energy Economics: Bergen, Norway, 2016.

18. Brunekreeft, G.; Buchmann, M.; Meyer, R. New developments in electricity markets following large-scale integration of renewable energy. In The Routledge Companion to Network Industries; Routledge: Abington, UK, 2015.

19. EC (European Commission). Digitizing the Energy Sector: An Opportunity for Europe. Available online: https:/ / ec.europa.eu/digital-single-market/en/blog/digitising-energy-sector-opportunity-europe (accessed on 16 March 2018).

20. Jenkins, D.P.; Patidar, S.; Simpson, S.A. Quantifying change in buildings in a future climate and their effect on energy systems. Buildings 2015, 5, 985-1002. [CrossRef]

21. Crosbie, T.; Broderick, J.; Short, M.; Charlesworth, R.; Dawood, M. Demand response technology readiness levels for energy management in blocks of buildings. Buildings 2018, 8, 13. [CrossRef]

22. Skytte, K.; Bergaentzlé, C.; Roselund Soysal, E.; Olsen, O.J. Design of grid tariffs in electricity systems with variable renewable energy and power to heat. In Proceedings of the 14th International Conference on the European Energy Market (EEM), Dresden, Germany, 6-9 June 2017; pp. 1-7.

23. RIL (Finnish Association of Civil Engineers). RIL 265-2014, Uusiutuvien lähienergioiden käyttö rakennuksissa (In English: Utilization of Local Renewable Energies in Buildings); RIL: Tampere, Finland, 2014.

24. Kastner, I.; Stern, P.C. Examining the Decision-making Processes behind Household Energy Investments: A review. Energy Res. Soc. Sci. 2015, 10, 72-89. [CrossRef]

25. Georgiadou, M.C. Future-proofed energy design approaches for achieving low-energy homes: Enhancing the code for sustainable homes. Buildings 2014, 4, 488-519. [CrossRef]

26. Akadiri, P.O.; Ezekiel, A.C.; Olomolaiye, P.O. Design of a sustainable building: A conceptual framework for implementing sustainability in the building sector. Buildings 2012, 2, 126-152. [CrossRef]

27. Fleiß, E.; Hatzl, S.; Seebauer, S.; Posch, A. Money, not morale: The impact of desires and beliefs on private investment in photovoltaic citizen participation initiatives. J. Clean. Prod. 2017, 141, 920-927. [CrossRef] 
28. Mahamatra, K.; Gustavsson, L. An adopter-centric approach to analyze the diffusion patterns of innovative residential heating systems in Sweden. Energy Policy 2008, 36, 577-590. [CrossRef]

29. Auvinen, K.; Lovio, R.; Jalas, M.; Juntunen, J.; Liuksiala, L.; Nissilä, H.; Mueller, J. FinSolar: Aurinkoenergian Markkinat Kasvuun Suomessa. Aalto University. Available online: https:/ /aaltodoc.aalto.fi/bitstream/ handle/123456789/20264/isbn9789526067674.pdf?sequence=1\&isAllowed=y (accessed on 4 January 2018). (In Finnish)

30. EC (European Commission). Climate Action. 2030 Climate \& Energy Framework. Available online: https:/ / ec.europa.eu/clima/policies/strategies/2030_en (accessed on 31 January 2017).

31. EC (European Commission). 2050 Energy Strategy. Available online: https://ec.europa.eu/energy/en/ topics/energy-strategy/2050-energy-strategy (accessed on 31 January 2017).

32. MotE (Ministry of the Environment). C2. The National Building Code of Finland (on Humidity). Available online: https:/ / www.edilex.fi/data/rakentamismaaraykset/c2.pdf (accessed on 26 July 2016).

33. MotE (Ministry of the Environment). C4. The National Building Code of Finland (on Thermal Insulation). Available online: https:/ / www.edilex.fi/data/rakentamismaaraykset/c4e.pdf (accessed on 11 July 2017).

34. MotE (Ministry of the Environment). D1. The National Building Code of Finland (on Water and Sewerage Systems of Building). Available online: https://www.edilex.fi/data/rakentamismaaraykset/D1_2007.pdf (accessed on 11 July 2017).

35. MotE (Ministry of the Environment). D2. The National Building Code of Finland (on Indoor Climate and Ventilation). Available online: http:/ / www.finlex.fi/data/normit/37187-D2-2012_Suomi.pdf (accessed on 25 July 2016).

36. MotE (Ministry of the Environment). D3. The National Building Code of Finland (on Energy Efficiency of Buildings). Available online: http:/ / www.finlex.fi/data/normit/37188-D3-2012_Suomi.pdf (accessed on 25 July 2016).

37. MotE (Ministry of the Environment). Energiakaivo, Maalämmön Hyödyntäminen Pientaloissa (In English: Energy Well, Utilization of Geothermal Heat in Small Houses). Available online: https:/ helda.helsinki.fi/ bitstream/handle/10138/40953/YO_2013.pdf?sequence=4 (accessed on 5 November 2016).

38. MotE (Ministry of the Environment). Ympäristöministeriön Asetus Rakennuksen Energiatodistuksesta (In English: The Decree on Energy Certification of Buildings). Available online: http:/ /www.ym.fi/fi-FI/ Maankaytto_ja_rakentaminen/Lainsaadanto_ja_ohjeet/Rakentamismaarayskokoelma/Energiatehokkuus (accessed on 3 May 2018).

39. MotE (Ministry of the Environment). D5. The National Building Code of Finland (on Calculation of Energy Consumption and Heat Demand). Available online: http:/ / www.finlex.fi/data/normit/29520-D5-190607suomi.pdf (accessed on 26 July 2016).

40. EC (European Commission). Background Report on EU-27 District Heating and Cooling Potentials, Barriers, Best Practice and Measures of Promotion. Scientific and Policy Report. Available online: https:/ / ec.europa. eu/ (accessed on 13 October 2017).

41. Hughes, L. Meeting residential space heating demand with wind-generated electricity. Renew. Energy 2010, 35, 1765-1772. [CrossRef]

42. IEA. Tracking Progress: Energy Storage. Available online: https://www.iea.org/etp/tracking2017/ energystorage/ (accessed on 15 March 2018).

43. Karnouskos, S. Demand Side Management via Prosumer Interactions in a Smart City Energy Marketplace. In Proceedings of the 2nd IEEE PES International Conference and Exhibition on Innovative Smart Grid Technologies, Manchester, UK, 5-7 December 2012. [CrossRef]

44. IAA (Indoor Air Association of Finland). Sisäilman Tekijät (In English: Indoor Air Components). Available online: http:/ / www.sisailmayhdistys.fi/Terveelliset-tilat/Sisailmasto/Sisailman-tekijat (accessed on 10 November 2016).

45. OfRH (Organization for Respiratory Health in Finland (Hengitysliitto)). Kuiva ja kostea ilma (In English: Dry and Humid Air). Available online: http://www.hengitysliitto.fi/fi/sisailma/hiukkasmaiset-jakaasumaiset-epapuhtaudet/kuiva-ja-kostea-ilma (accessed on 5 June 2016).

46. RIL (Finnish Association of Civil Engineers). RIL 249-2009 Matalaenergiarakentaminen Asuinrakennukset (In English: Low-Energy Construction, Residential Buildings), 2nd ed.; Suomen Rakennusinsinöörien Liitto RIL ry.; Saarijärven Offset Oy: Saarijärvi, Finland, 2009; ISBN 978-951-758-517-0. 
47. Vinokurov, M.; Luoranen, M. Regional energy model based approach to identify new business opportunities while increasing energy efficiency. In Proceedings of the CIB World Building Congress, Tampere, Finland, 30 May-3 June 2016.

48. EUR-Lex. Directive of the European Parliament and of the Council of 19 May 2010 on the Energy Performance of Buildings (Recast) EUVL 2016a, 153, 18.6.2010. Available online: http:/ / eur-lex.europa.eu/legal-content/ EN/TXT/?uri=CELEX\%3A32010L0031 (accessed on 9 November 2016).

49. EUR-Lex. 517/2012 EU, Regulation of the European Parliament and the Council on Fluorinated Greenhouse Gases. Available online: http:/ / eur-lex.europa.eu/legal-content/EN/TXT/?uri=celex\%3A32014R0517 (accessed on 11 December 2016).

50. Finlex. Land Use and Building Act (132/1999, MRL). Available online: http://www.finlex.fi/fi/laki/ ajantasa/1999/19990132 (accessed on 9 December 2016).

51. Finlex. Land Use and Building Directive (895/1999). Available online: http://www.finlex.fi/fi/laki/ ajantasa/1999/19990895 (accessed on 9 December 2016).

52. FLEXe. The Final Report of the Research Project FLEXe (Flexible Energy System). Available online: http: / / flexefinalreport.fi/content/ prosumers (accessed on 21 March 2018).

53. Ijäs, S. District Heating Connection Obligation. Available online: http://www.kunnat.net/fi/tietopankit/ tapahtumat/aineisto/2015/kuntamarkkinat/lakiklinikka/Documents/Ij\%C3\%A4s\%20Susanna-Kaukol\% C3\%A4mp\%C3\%B6\%C3\%B6n\%20liittymisvelvollisuus-KUMA\%202015.pdf (accessed on 18 December 2016).

54. Boomsma, T.K.; Meade, N.; Fleten, S.-E. Renewable energy investments under different support schemes: A Real Options Approach. Eur. J. Oper. Res. 2012, 220, 225-237. [CrossRef]

55. Simola, A.; Kosonen, A.; Ahonen, T.; Ahola, J.; Korhonen, M.; Hannula, T. Optimal dimensioning of a solar PV plant with measured electrical load curves in Finland. Sol. Energy 2018, 170, 113-123. [CrossRef]

56. Vimpari, J.; Junnila, S. Evaluating decentralized energy investments: Spatial value of on-site PV electricity. Renew. Sustain. Energy Rev. 2017, 70, 1217-1222. [CrossRef]

57. Wei, C.; Li, Y. Design of Energy Consumption Monitoring and Energy-saving Management System of Intelligent Building Based on the Internet of Things. In Proceedings of the 2011 International Conference on Electronics, Communications and Control, Ningbo, China, 9-11 September 2011; pp. 3650-3652.

58. GBC (Green Building Council) Finland. Rakennusten Elinkaarimittarit 2013 (In English: The Life Cycle Indicators of Buildings 2013). Available online: http://figbc.fi/wp-content/uploads/2013/01/ Rakennusten_elinkaarimittarit_2013.pdf (accessed on 23 March 2018).

59. GBC (Green Building Council) Finland. Life-Cycle Cost-The Long-Term Cost Efficiency Indicator. Available online: http:/ / figbc.fi/en/building-performance-indicators/calculation-guide/life-cycle-costguide/ (accessed on 29 October 2017).

60. Kniefel, J. Life-cycle carbon and cost analysis of energy efficiency measures in new commercial buildings. Energy Build. 2010, 42, 333-340. [CrossRef]

61. VTT. Puurakenteiden Kosteustekninen Toiminta (In English: Hygroscopic Performance of Wooden Stucturs). Available online: https:/ / www.vtt.fi/inf/pdf/tiedotteet/1999/T1991.pdf (accessed on 2 March 2018).

62. Energiavirasto (Energy Authority). Hintatilastot (In English: Price Statistics). Available online: http: //www.sahkonhinta.fi/summariesandgraphs (accessed on 2 March 2018).

63. VTT. Tehokas ja ympäristöä säästävä tulisijalämmitys (In English: Efficient and Environment Friendly Fireplace Heating). Available online: http:/ / www.vtt.fi/inf/julkaisut/muut/2008/VTT-R-10553-08.pdf (accessed on 2 March 2018).

64. Rakennustieto. ROK Rakennusosien Kustannuksia 2014 (In English: Costs of the Building Components 2014); Rakennustieto: Helsinki, Finland, 2014; pp. 209-210.

65. Rakennustieto. ROK Rakennusosien Kustannuksia 2017 (In English: Costs of the Building Components 2017); Rakennustieto: Helsinki, Finland, 2017.

66. VTT. Maalämmön ja-Viilennyksen Hyödyntäminen Asuinkerrostalon Lämmityksessä ja Jäähdytyksessä (In English: Utilization of Ground Source Heat Pump in Heating and Cooling of the Residential Building). Available online: http:/ / www.vtt.fi/inf/pdf/tiedotteet/2010/T2546.pdf (accessed on 5 March 2018).

67. FinSolar. Aurinkosähköjärjestelmien Hintatasot ja Kannattavuus (In English: Price Levels and Viability of Solar Electricity Systems). Available online: http:/ / www.finsolar.net/aurinkoenergian-hankintaohjeita/ aurinkosahkon-hinnat-ja-kannattavuus / (accessed on 6 March 2018). 
68. Imatran Seudun sähkö Oy (Local Energy Utility). Liittymismaksuhinnasto (In English: Connection Fee Pricelist). Available online: http:/ / www.issoy.fi/sahkonsiirto/hinnastot/liittymismaksuhinnasto (accessed on 7 September 2017).

69. NREL (National Renewable Energy Laboratory). Photovoltaic Degradation Rates-An Analytical Review. Available online: https:/ / www.nrel.gov/docs/fy12osti/51664.pdf (accessed on 3 April 2018).

70. Energiavirasto (Energy Authority). Sähköntuotannon Päästökerroin (In English: Emission Factor of Electricity Production). Available online: https://www.energiavirasto.fi/sahkontuotannon-paastokerroin (accessed on 2 March 2018).

71. DoE (U.S. Department of Energy). Guide to Geothermal Heat Pumps. Available online: https://energy.gov / sites/prod/files/guide_to_geothermal_heat_pumps.pdf (accessed on 13 October 2016).

72. Kahola, M. Kotitalouksien Aurinkosähkön Kannattavuus Suomessa-Mahdolliset Tukivaihtoehdot ja Niiden Kustannukset. Master's Thesis, Pro gradu. Tampere University of Technology. TamPub, Tampere, Finland, 2015.

73. Rakennustieto. Kiinteistön Tekniset Käyttöiät ja Kunnossapitojaksot (In English: Technical Service Lives and Maintenance Periods of Buildings). LVI 01-10424. 2008. Available online: https: / / www.rakennustieto.fi / kortistot/lvi/kortit/10424 (accessed on 1 March 2018).

74. Energiatehokas Koti. Lämmitysjärjestelmien Elinkaari (In English: Technical Service Life of Heating Systems). Available online: http:/ / www.energiatehokaskoti.fi/suunnittelu/talotekniikan_suunnittelu/lammitys / lammitysjarjestelmien_elinkaari (accessed on 6 February 2018).

(C) 2018 by the authors. Licensee MDPI, Basel, Switzerland. This article is an open access article distributed under the terms and conditions of the Creative Commons Attribution (CC BY) license (http:/ / creativecommons.org/licenses/by/4.0/). 